\title{
Management of Village Credit Institutions in Buleleng District (Independent Sanction Perspective)
}

\author{
Nyoman Sukandya ${ }^{1}$, I Wayan Rideng ${ }^{2}$, I Nyoman Putu Budiartha ${ }^{3}$ \\ wayan_rideng@yahoo.co.id ${ }^{1}$ \\ Faculty of Law, Universitas Warmadewa, Denpasar-Bali, Indonesia ${ }^{123}$
}

\begin{abstract}
This research is aiming at carrying out a cultural mission to carry out activities internally within the community, and oriented toward improving the welfare of indigenous village communities. The provincial government of Bali is in a position as semi-intervention so that the management is giving the power to decide. The research method used is by conducting interviews so that this type of research qualifies as a type of empirical sociological research. In the discussion related to the policies carried out by the Provincial Government of Bali, the LPD was only semi-intervention in the form of the issuance of Regional Regulations and was semi-autonomous concerning its management. Then in managing activities, there are several LPDs in Buleleng Regency experiencing difficulties in handling credit settlement. So that it requires implementing customary sanction provisions, as stipulated in awig-awig or perarem in each traditional village. Then conclusions can be drawn that the Provincial Government of Bali has taken a semi-intervention position in the regulation of Village Credit Institutions (LPD) and provides semi-autonomous locations to traditional villages in managing their management. This provision shows as a form of Self-Regulatory well in LPD settings. Then the application of the sort of customary sanctions is based on the regulations that have been arranged in the awig-awig or pararem in each traditional village/pakraman.
\end{abstract}

Keywords: Customary Sanctions, Village Credit Institutions (LPD).

\section{Introduction}

The economy of Bali is very dependent on tourism activities. Tourism on the island of Bali is supporting by art and culture. Therefore, culture is the breath of economic life in Bali. The tourism sector is the main driving force for all industries of goods and services. Bali with its unique variety is always an attraction for tourists. For this reason, the tourism development sector is well developed. Various forms of cultural diversity, such as; religious ritual systems, customs, marriage systems, building architecture, and different other systems that build unity of Balinese cultural identity is maintained and preserved. As the foundation of Balinese culture, the existence of traditional villages (pakraman) is very important and strategic where its presence constitutionally regulated through the provisions of Article 18 B paragraph (2) governing the existence of traditional villages in Bali, its existence carrying 2 (two) main functions, namely; cultural functions and economic functions. The purpose of culture as the function of cultural preservation and development while the economic function is the maintenance and construction of culture as economic potential, as well as economic 
institutions belonging to traditional villages to sustain the needs in the implementation of their functions.

Indigenous peoples in Bali, according to their nature and function, are social-religious and socio-economic institutions. Indigenous peoples have clear objectives, organizations, personnel, and management (customary institutions). Customary leadership is an element of the institution that carries out all institutional provisions and policies, both written and unwritten. One of the outlines of the tasks/functions is related to managing the wealth of traditional villages for the welfare of indigenous village communities in the fact that the role of customary villages is not limited to socio-cultural and religious characters, but also the part of the economy and public services originating from the government. Customary villages carry out various functions, both in the context of their existence as native villages and as elements of the nation. Such a significant role has illustrated the variety of functions and the number of costs that must be born as a burden by traditional villages in their daily lives. The fee is not limited to financing for his affairs, but also additional relations that come from the government. In carrying out activities, the fact is that traditional villages are outside the line of government financing policies, because in general customary village organizations are autonomous villages that are not part of the state government structure. Existence outside the structure, or not being part of the structure, the state organization also means that traditional villages are outside the structure of the state budget. For traditional villages in Bali, these conditions give rise to injustice in treating traditional villages. Customary Villages, on the one hand, carries out very heavy tasks, functions, both historical, social, and cultural, but on the other hand apart from the right to obtain support from the government to support the tasks and functions.

These problems by the Provincial Government of Bali are overcoming through the development of village economic institutions, especially traditional village financial institutions known as Village Credit Institutions (LPD), namely an institution formed, managed and owned by customary village (traditional village). The customary village is the manager and person in charge of this institution. The customary village is chosen as the foundation of the LPD, because:

a. Customary villages are traditional buildings that have been root and respected by rural communities, especially by krama (members);

b. Customary villages have rules, both written and unwritten;

c. Customary villages are traditional institutions and are group based on geographical customs, where there are social interactions that occur on a daily basis resulting in a growing sense of unity and natural cooperation as a manifestation of cooperation;

d. Customary villages have a substantial obligation and burden of responsibility when compared to their rights.

Since being formally introduced in Bali through the Regional Regulation of Bali Province, as recently as amended by the Regional Regulation of Bali Province Number 3 of 2017 concerning LPD. LPDs have several objectives, namely; First, to encourage the economic development of rural communities through directed relations and effective capital distribution. Second, eradicate the bondage system, dark pawn, and others that can be equal with it in the rural area. Third, creating equity and employment opportunities for rural residents. Fourth, creates purchasing power and expedites payment and exchange traffic in the village.

Based on the Provincial Regulation of Bali Number 3 of 2017 stated, that the objectives of LPD businesses are: 1) Encouraging economic development of rural communities through activities to collect savings and deposits from; 2). Eradicating bonded labor, dark pawns, and 
others that can be equal with it; 3). Creating equal opportunity to try and expand the possibilities of village manners, and 4th). Increase purchasing power and facilitate the payment and circulation of money in the village. One obstacle that can be faced by LPDs is the possibility of a smooth return on loans. Holloh states that there are two reasons why lending is low, namely: the absence of supervision of channeled loans and the high level of lending rates compared to financial institutions such as commercial banks. In practice for "borrowers" who do not fulfill their obligations to the LPD to make payments, customary sanctions are applied. In customary law, there is indeed no distinction between criminal and civil contexts. Often, the application of customary sanctions is indeed useful in enforcing LPD management rules. But many people consider the use of sanctions to be just a bitter pill, which is thought to cause further impacts besides often being deemed inhuman and not in line with the purpose of its formation. The following characteristics indicate LPD as a financial institution in its activities:

a. Belongs to the customary village;

b. Formed and managed by customary village;

c. Carry out the institutional financial functions of the customary village community, such as receiving/collecting funds from village officials, providing loans only to village officials, and

d. Carrying out business functions as private financial business institutions in customary village, or as far as possible traditional village/pakraman.

These characteristics indicate that LPD is a community financial institution formed by a community unit, operating within a community area, serving environmental, financial transactions or for the benefit of community members, to fulfill community goals. They interact according to a system of customs and bound by a strong sense of identity. In Buleleng Regency there are 169 LPDs that are spread over 158 traditional villages. In the development, there were several LPDs that not spared from the problems that were not smooth for the customers who were members of the traditional village manners to fulfill their obligations. So sometimes to collect it through the application of customary sanctions. In connection with the above explanation, there are legal issues that form the basis for formulating the above problems, namely: 1) How do you implement Self-Regulation in the Management of Village Credit Institutions? 2nd). How is the application of customary sanctions in the management of village credit institutions in Buleleng Regency?

\section{Methodology}

The type of research used in this study is a type of empirical legal research, namely research that examines the law, not only as a passive norm but the law and regulations in its implementation, or commonly called non-doctrinal or socio-legal research. This is based on the idea that this study is against the application of sanctions, especially customary sanctions in the context of managing LPD in Buleleng Regency. This type of empirical legal research is also called a variety of sociological, legal research. In this study in approaching the problem under study it is used a sociological juridical approach, which emphasizes on anthropological studies intended to obtain a complete and in-depth picture of the legal behavior of each actor in a community.

This research was carried out in Buleleng Regency on the existence of LPDs in each traditional village whose existence was strongly supported by financial institutions in traditional villages namely, LPD. As for the considerations: 1) Because in each traditional 
village has a financial institution that can support the program/activity in each of its working areas/authorities, 2) That each traditional village in management always regulates the people must fulfil rights and obligations, especially in regulating the provisions of obligations. Third) Provisions for sanctions for members of customary village (krama) that do not fulfill obligations have been regulate through awig-awig.

In this study the types of data obtained from various sources, which include primary data and secondary data. Field data as primary data in this study were collected from the management of LPD and traditional village teachers in each customary village which sampled in the collection of research data. For this type of secondary data, it is obtained by conducting a search of several kinds of literature and laws and regulations or authentic proofs that regulate the people who do not fulfill obligations that are subject to customary sanctions and regulated through Awig-awig and their respective traditional village pararem.

\section{Result and Discussion}

\subsection{Characteristics of LPDs as Economic Institutions of Customary Law Communities in Bali}

Article 1 number 9 of Bali Province Regional Regulation Number 3 of 2017 concerning Amendments to Bali Province Regional Regulation Number 3 of 2007 Village Credit Institutions (LPDs) define LPDs as financial institutions belonging to Customary village which are located in the authority of customary village. The word "property" shows that the institution is an institution formed and managed by Customary village for the benefit of customary village. Furthermore, in Article 3 of the Provincial Regulation of Bali Number 3 of 2017 regulates the operation of the LPD, namely the LPD carries out business operations in the Village and for the members (Krama Desa). Empirically, the characterized of the LPD is several institutional administrators, such as; the founder, the basis for the establishment, institutional elements, scope of activities, and functions of the LPD in the event of the customary village. The LPD was established by customary village, not created by the provincial government or district/city government. In its establishment based on instruments from awig-awig and Perda not based on company legal instruments or banking legal instruments, namely notary deeds. LPDs in their institutional status is not obtained based on the approval of the Government or the Minister based on pararem. The LPD was established with the aim of supporting the implementation of the functions of the customary village. Not intended to seek maximum profit. Such reality is very different from the purpose of establishing banking businesses, both in the form of PTs and cooperatives which are aimed solely at business interests, both for its members and shareholders.

\subsection{Awig-Awig as A Form of Application of Self-Regulatioan in Management of LPD}

Customary village is given full rights to take care of its internal community affairs. The internal management of the Customary village community is regulated in the village provisions (awig-awig). Customary village is the largest unit that covers the entire subcommunity unit within the city but does not intervene in the internal management of each group. The limits are religious rules, village governance, living procedures, and environmental arrangements that are regulated and applied in the customary village. Regarding the existence of the LPD, in general, the awig-awig customary village does not include LPD as a form of 
village ownership. To regulate the presence of the LPD, special rules were specifically agreed upon through the Customary village meeting. This provision is commonly called pararem which specifically regulates LPDs. Regulations regarding this matter in each Customary village give another name. As one of the LPDs that became the sample, namely the LPD of Ambengan Village determines in the perarem the name Pararem Desa Perkreditan Lembaga (LPD) Desa Pakraman Ambengan. The formation and management mechanism has no intervention from the regional government. Whereas in determining the management of the LPD, it was chosen through the paruman of customary village. The entire selection process to produce the selected ones as administrators are determined by customary village. Thus, it shows that even though there are standards for the formation and management of LPD based on the Perda, the structure and determination of LPD administrators is based more on awigawig. Mechanisms and procedures in the process of determining the candidates for management, the selection and decision of administrators have been arranged in awig-awig or pararem. Likewise in the imposition of sanctions, in the form of customary sanctions.

\section{Conclusion}

The Provincial Government of Bali has taken a semi-intervention position in the regulation of the LPD and provided a semi-autonomous position to the customary village in regulating and administering LPD management. The provision is intended to continue to respect the position and function of Customary village as a unit of indigenous peoples. There is a balance between the position of the Provincial, Regency / City Government and Customary village in the arrangement of the LPD. Shows as a form of Self-Regulatory well in LPD settings. Application of customary sanctions in the management of LPD in Buleleng Regency is carried out based on the provisions that have been arranged in awig-awig or pararem in each customary village. Before customary sanctions are imposed, guidance is provided by involving traditional leaders (prajuru adat). The forms of sanctions he imposed between customary village with one another are not the same. But the spirit is almost the same, namely saving the wealth of customary village. The application of sanctions is carried out through village paruman.

\section{References}

[1] Abdulkadir, M.: Hukum dan Penelitian Hukum. Citra Aditya Bhakti, Bandung (2010)

[2] Ashofa, B.: Metoda Penelitian Hukum. Rineka Cipta, Jakarta (2004)

[3] Holloh, D.: Microfinance Institutions Study. ProFI, Jakarta (2001)

[4] Koentjaraningrat.: Pengantar Ilmu Antrologi. Aksara Baru, Jakarta (1980)

[5] Ramantha, I W.: Menuju LPD Sehat. Buletin Studi Ekonomi. Vol.11(1) (2003)

[6] Widyana, I M.: Kapita Selekta Hukum Pidana Adat. Eresco, Bandung (1993)

[7] Windia, I W.P.: Hukum Adat Bali; Aneka Kasus dan Penyelesainnya. Udayana Universirty (2014)

[8] Perda Provinsi Daerah Tingkat I Bali Nomor 2 tahun 1988 tentang Lembaga Perkreditan Desa (1988)

[9] Perda Provinsi Bali Nomor 6 tahun 1986 tentang Peran dan Fungsi serta Kedudukan Desa Pakraman (1986)

[10] Perda Provinsi Bali Nomor 3 tahun 2001 tentang Desa Pakraman (2001)

[11] Perda Provinsi Bali Bomor 3 tahun 2017 tentang LPD sebagai pengganti Perda Provinsi Bali Nomor 8 tahun 2002 tentang LPD (2017) 
[12] Sukandya, N.: Kedudukan Hukum Dan Fungsi Lembaga Perkreditan Desa (LPD) Sebagai Lembaga Perekonomian Komunitas Dalam Masyarakat Hukum Adat di Bali. Disertasi Program Studi Doktor Ilmu Hukum, Universitas Brawijaya-Malang (2012) 